\title{
Agronomic performance of sunflower intercropped with
}

\section{Urochloa ruziziensis}

\section{Desempenho agronômico do girassol consorciado com Urochloa ruziziensis}

\author{
Anderson Morais KIMECZ ${ }^{1}$; Wellington Junior Candido da SILVA ${ }^{1}$; Diego Hahn MACHADO'; \\ Giovane STEIN ${ }^{1}$; Flávio Carlos DALCHIAVON²
}

\begin{abstract}
${ }^{1}$ Engenheiros Agrônomos, Instituto Federal de Educação, Ciência e Tecnologia de Mato Grosso, Campus Campo Novo do Parecis, curso de Bacharelado em Agronomia, MT 235, km 12, Zona Rural, Campo Novo do Parecis/MT - CEP 78360- 000, anderson_kimecz@live.com, wellingtoncandido.cnp@hotmail.com, diegoh26@hotmail.com, giovane-26@hotmail.com

${ }^{2}$ Autor para correspondência. Engenheiro Agrônomo, Doutor em Agronomia, Professor no Instituto Federal de Educação, Ciência e Tecnologia de Mato Grosso, Campus Campo Novo do Parecis, curso de Bacharelado em Agronomia, MT 235, km 12, Zona Rural, Campo Novo do Parecis/MT - CEP 78360-000, flavio.dalchiavon@cnp.ifmt.edu.br
\end{abstract}

Recebido em: 08-05-2018; Aceito em: 20-08-2018

\begin{abstract}
Sunflower cultivation is a viable alternative for the second crop in Campo Novo do Parecis, state of Mato Grosso; however, its low contribution to the land cover after harvest is an obstacle for the practice of the no - tillage system, which favors the maintenance of straw on the soil. The objective of this study was to evaluate the influence of the intercropping on the agronomic performance and yield of sunflower under different populations of Urochloa ruziziensis in the region of Parecis. The experiment was carried out in the experimental field in the Instituto Federal do Mato Grosso, campus Campo Novo do Parecis, state of Mato Grosso in the second crop of the 2016/17 agricultural year. The experimental design was a randomized complete block design with six treatments $(0,200$, $400,600,800$ and 1000 points of cultural value ha ${ }^{-1}$ of $U$. ruziziensis) and four replications. Sowing was performed on March $10^{\text {th }}, 2017$ using variety Helio 250. No significant effect was found among treatments neither did the mathematical regressions present statistical significance. The agronomic characteristics of the sunflower are not influenced by Urochloa ruziziensis sowing rates when sowed simultaneously due to the slow initial growth of the grass and the competitive efficiency of the sunflower after 30 days of the cycle.
\end{abstract}

Additional keywords: grass; Helianthus annuus; no-tillage system; soil cover and soil preservation.

\section{Resumo}

A cultura do girassol mostra-se uma alternativa viável para segunda safra em Campo Novo do Parecis - MT, porém sua baixa contribuição com a cobertura do solo, após a colheita, dificulta a adoção da prática do sistema plantio direto, o qual preza pela manutenção de palhada no solo. Assim, objetivou-se avaliar a influência do consórcio no desempenho agronômico e na produtividade do girassol sob diferentes populações de Urochloa ruziziensis na região do Parecis. O experimento foi realizado no campo experimental do Instituto Federal de Mato Grosso, Câmpus Campo Novo do Parecis-MT, na segunda safra do ano agrícola de 2016/2017. O delineamento experimental foi o em blocos casualizados, com seis tratamentos (0;200; 400; 600; 800 e 1000 pontos de valor cultural ha-1 de $U$. ruziziensis) e quatro repetições. A semeadura foi realizada no dia 10-03-17, com a variedade Helio 250. Não houve diferença significativa entre os tratamentos, assim como as regressões matemáticas não apresentaram significância estatística. As características agronômicas do girassol não são influenciadas pelas taxas de semeadura da Urochloa ruziziensis, quando semeadas simultaneamente, devido ao lento desenvolvimento inicial da gramínea e a eficiência competitiva do girassol a partir de 30 dias do ciclo.

Palavras-chave adicionais: cobertura vegetal e preservação do solo; gramínea; Helianthus annuus; sistema plantio direto.

\section{Introduction}

The sunflower (Helianthus annuus L.) is an annual dicotyledon plant of the family Asteraceae, highly adaptable to several soil-climate conditions. It is cultivated in all continents for the production of comestible oils, biodiesel, ornamentation, animal feed and others (Souza et al., 2015). Sunflower crop culture in Brazil is feasible as from the second harvest, especially for the state of Mato Grosso in the Central-Western region, represented almost exclusively for the municipality of Campo Novo do Parecis. Cultivated area in Brazil for the 2016/17 harvest reached 62.7 thousand ha, of which 50.1 thousand were cultivated in the three states of the Central-Western region. The state of Mato Grosso featured a 31.8 thousand ha crop area. Brazilian production for the 2016/17 harvest amounted to 103.7 thousand tons. The Central-Western region 
featured 85.3 thousand tons, with the state of Mato Grosso producing 53.1 thousand tons for the entire region. Once more, Campo Novo do Parecis was the municipality with the highest production rate in the state (Conab, 2018). In fact, the municipality has the best soil-climate conditions, with the best altitude and a well-defined dry season.

The no-tillage system (NTS) is widely employed in the region since it minimizes soil and nutrient losses by erosion. The sunflower crop is not efficient for soil coverage. Least soil coverage after harvest lies in residues, predominantly by stalks (Marcelo et al., 2012).

In the case of the maintenance of straw and chaff for the feasibility of NTS, grasses produce great mass volumes. Since they have a high $\mathrm{C} / \mathrm{N}$ ratio, they endure longer in soil coverage (Noce et al., 2008). Intercropping requires defining grass population so that high population rates of the latter do not impair the development of the main crop and benefit soil coverage.

Species of the genus Urochloa are widely used in intercropping for soil coverage during the interharvest period or in the formation of pasture within integrated systems. As a rule, Urochloa grasses are the main options in chaff formation for NTS due to the production of good dry matter and to high $\mathrm{C} / \mathrm{N}$ ratio in their composition formed by great lignin concentrations which prolong their decomposition span (Nepomuceno et al., 2012). Machado \& Assis (2010) report that Uruchloa ruziziensis and Uruchloa decumbens may be better employed for soil coverage since they have continuous growth during the dry season and fast drying rates.

Although the sunflower may be intercropped with grass species, negative effects (with loss of productivity) may occur due to greater interspecies competition (Alves et al., 2013). Gontijo Neto et al. (2009) assessed sunflower intercropping with Xaraés, Piatã and Massai cultivars and reported a $27 \%$ decrease in sunflower productivity when compared to sunflower crop alone. When Souza et al. (2015) compared sunflower intercropped with $U$. ruziziensis planted in the first fortnight in February, they registered a $540 \mathrm{~kg} \mathrm{ha}^{-1}$ $\left(1180.0-1720.0 \mathrm{~kg} \mathrm{ha}^{-1}\right)$ increase in sunflower productivity in contrast to sunflower crop alone. The above signaled the need for more in-depth studies on the intercropping sunflower culture to define the correct parameters for the system's best efficiency.

Sunflower intercropping with grass has become an interesting technique to solve the issue of low vegetal coverage after harvest within the sunflower crop alone system. However, the system's influence on crop development and productivity should be evaluated to avoid possible negative effects on it. Current assay assessed the influence of intercropping in agronomic performance and productivity of the sunflower under different populations of Urochloa ruziziensis in the Campo Novo do Parecis region.

\section{Material and methods}

Current assay was performed in Campo Novo do Parecis MT Brazil, in the second 2016/2017 harvest. The area lies at $13^{\circ} 40^{\prime} 37^{\prime \prime} S$ and $57^{\circ} 47^{\prime} 30^{\prime \prime}$ ' W and altitude $564 \mathrm{~m}$. The soil of the experimental area is typical dystrophic Red-Yellow Latosol, following the Brazilian Soil Classification System (Embrapa, 2013). According to Köppen's classification (Vianello \& Alves, 2004), local climate is Aw, or rather, tropical climate with a well-defined dry season between May and September. The dry and rainy seasons are welldefined, the former between May and September, the latter between October and April (Dallacort et al., 2011). Figure 1 provides data on mean rainfall and temperature rates during the experimental period. Mean rates were $31.0 ; 23.2$ and $18,2{ }^{\circ} \mathrm{C}$ for maximum, mean and minimum temperatures, respectively; rainfall reached $510.4 \mathrm{~mm}$ during the experimental period, complying with sunflower's water demands, between 500 and $700 \mathrm{~mm}$, regularly distributed throughout the cycle (Castro \& Farias, 2005).

The experiment consisted of randomized blocks with six treatments (seeding rates of $U$. ruziziensis), with four replications. Treatments comprised $0,200,400,600,800$ and 1000 scores of crop value $(\mathrm{CV})$ per ha $^{-1}$. To calculate number of seeds, CV percentage was determined by Equation 1 (Gontijo Neto et al., 2006):

CV $(\%)=(\%$ purity $\times \%$ germination $) / 100$

Wherein: \% purity is the physical quality of $U$. ruziziensis seeds, or rather, the number of $U$. ruziziensis seeds on total number of seeds of the sample, including dirt (stones and chaff); \% germination is the number of viable seeds.

Quantity of seeds was calculated by Equation 2 (Gontijo Neto et al., 2006):

AS $\left(\mathrm{kg} \mathrm{ha}^{-1}\right)=$ SCV / CV (\%)

Wherein: AS is the amount of seeds $\left(\mathrm{kg} \mathrm{ha}^{-1}\right)$; CV score is the desired seeding rate.

Since U. ruziziensis seed is $100 \%$ pure and $88 \%$ germination, amount of seeds for CV scores were $2.27 ; 4.55 ; 6.82 ; 9.09$ and $11.36 \mathrm{~kg} \mathrm{ha}^{-1}$ respectively for $200,400,600,800$ and 1000 SCV.

The planting of sunflower, cultivar Helio 250, was done mechanically with broadcast spreader on 10-03-2017. Splits comprised six $7 \mathrm{~m}$ rows, spaced $0.45 \mathrm{~m}$, with 45,000 plants ha-1. Useful area comprised two central rows, excluding $1 \mathrm{~m}$ from each edge. $U$. ruziziensis was seeded manually, posterior to seeding of sunflower, followed by surface incorporation by rake. The sunflower plant emerged some 5 days after seeding (DAS) and $U$. ruziziensis emerged between 8 and 20 DAS.

Basic fertilization for sunflower requirements complied with recommendations by Leite et al. (2005) through the chemical analysis of soil. The following were applied: $10 \mathrm{~kg} \mathrm{ha}^{-1} \mathrm{~N} ; 70 \mathrm{~kg} \mathrm{ha}^{-1} \mathrm{P}_{2} \mathrm{O}_{5} ; 60 \mathrm{~kg} \mathrm{ha}^{-1}$ 
$\mathrm{K}_{2} \mathrm{O} ; 2 \mathrm{~kg} \mathrm{ha}^{-1} \mathrm{~B}$. Source comprised the formula 10-3020 in a dose of $200 \mathrm{~kg} \mathrm{ha}^{-1}$, plus $10 \mathrm{~kg} \mathrm{ha}^{-1} \mathrm{P}_{2} \mathrm{O}_{5}$ ( $\mathrm{sim}$ ples super phosphate) and $20 \mathrm{~kg} \mathrm{ha}^{-1} \mathrm{~K}_{2} \mathrm{O}$ (potassium chloride). Fertilization with $\mathrm{B}$ had Borosol as source
(14.6\% B). Fertilization of nitrogen coverage at a dose of $60 \mathrm{~kg} \mathrm{ha}^{-1}$ (urea) was performed after 30 days after emergence (DAE) of the sunflower.

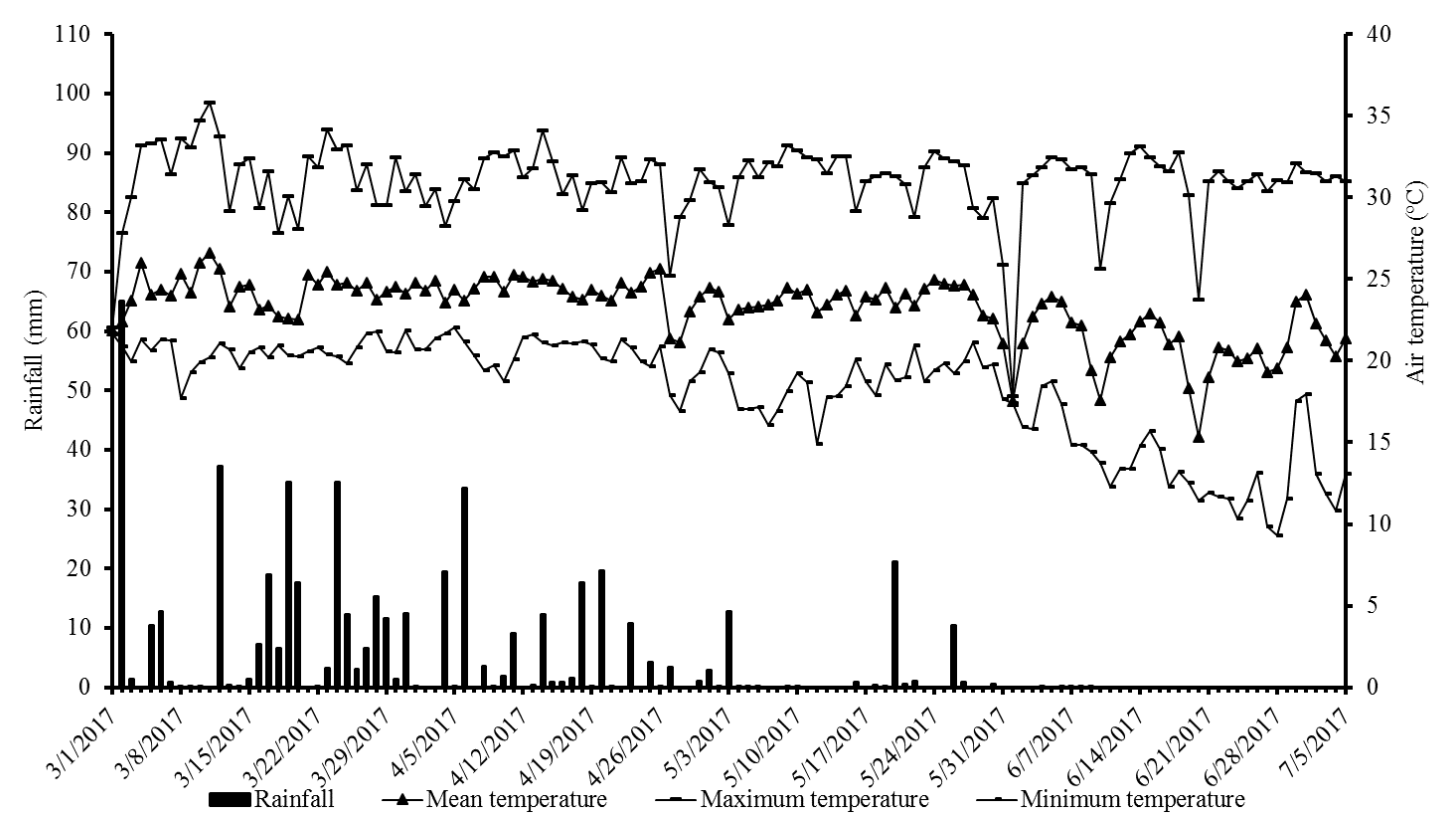

Figure 1 - Rainfall and mean air temperatures in the experimental area during 2017.

Weed control was done manually at 7,20 and 35 DAE. Pest and disease control was achieved by constant monitoring of the area. Control of inspectpests, such as cucurbit beetle (Diabrotica speciosa), sunflower patch (Chlosyne lacinia) and scarab beetle (Cyclocephala melanocephala), was performed by two applications of thiamethoxam + lambda cyhalothrin (141 $\mathrm{g} \mathrm{L}^{-1}+106 \mathrm{~g} \mathrm{~L}^{-1}$ i.a., respectively) at dose $250 \mathrm{~mL} \mathrm{ha}^{-1}$ at stages V4 and V6 of the plant; one application of alpha-cypermithrin (1000 g L-1 i.a.) at dose $100 \mathrm{~mL} \mathrm{ha}^{-1}$ at stage R1; and one application of acephate $\left(750 \mathrm{~g} \mathrm{~kg}^{-1}\right.$ i.a.) at dose $1 \mathrm{~kg} \mathrm{ha}^{-1}$ at stage R5. Difeconazole (250 $\mathrm{g} \mathrm{L}^{-1}$ i.a.) was applied twice for the control of Alternaria helianthi, at dose $0.3 \mathrm{~L} \mathrm{ha}^{-1}$, at stages V6 and R1. Applications were done with shoulder pump with compressed $\mathrm{CO}_{2}$ at constant pressure of $413,69 \mathrm{kPa}(60 \mathrm{psi})$.

Sunflowers were harvested manually with pruning shears on 05/07/2017 when the crop reached phenological stage R9 (physiological maturity). The crop was left to dry naturally; it was then weighed and corrected for humidity at $11 \%$ (hb), following Dalchiavon et al. (2011). The agronomic characteristics in R5.5 (full bloom) in five plants per split comprised plant height (PLH; $\mathrm{cm})$, measured by tape, from soil level to the highest tip of the plant; stalk diameter (STD; mm), measured by caliper from $5 \mathrm{~cm}$ above soil level; shoot dry mass (DMA; $t$ ha $^{-1}$ ), after drying of plants in an oven at $105^{\circ} \mathrm{C}$. Five capitula in R9 were evaluated: diameter of the capitulum (DCA; $\mathrm{cm}$ ) by tape; mass of capitulum (MCA; g) and mass of achene per capitulum (MAC, g) by a semi-analytic scale (sensitiveness $0.001 \mathrm{~g}$ ); number of achenes per capitulum (NAC), by grain counter (Modelo NV-C/01); mass of one thousand achenes (MTA, g); harvest index (HRI), by dividing the mass of achenes by the mass of the capitula. Productivity of achenes (PRA, $\mathrm{kg} \mathrm{ha}^{-1}$ ) was obtained by the production of all plants within the split's useful area.

Data underwent analysis of variance $(p<0.05)$ and regression, with SISVAR (Ferreira, 2011).

\section{Results and discussion}

There was no influence of treatments on the development of the sunflower (Table 1). Analysis of variance was not significant and mathematic regressions had no statistical significance. Coefficients of variance (CV) for agronomic characteristics of the sunflower were classified low or average, following classification suggested by Pimentel-Gomes (2009). They were similar to those reported by Souza et al. (2015) and Santos et al. (2016), who evaluated the agronomic characteristics of the sunflower intercropping species of the genus Urochloa.

Lack of influence of seeding rates of $U$. ruziziensis on the sunflower's characteristics (Tables 1 and 2) is due to the slow initial development of the grass when compared to that of the sunflower, registered by Timossi et al. (2007). The authors reported slow initial development of the species of the genus Urochloa. Similarly, Pacheco et al. (2008) observed low rates for plant height in species of the genus Urochloa when compared to millet, yardgrass 
and sorghum 30 days after seeding (DAS) and in four seeding periods.

Pacheco et al. (2008) stated that, whereas mean heights of the four periods for the species Urochloa (ruziziensis, decumbens and brizantha) were respectively $12.64,14.88$ and $14.4 \mathrm{~cm}$, height of millet reached $18.05 \mathrm{~cm}$, yardgrass reached $19.21 \mathrm{~cm}$ and sorghum reached $29.49 \mathrm{~cm}$, or rather, higher rates than those by Urochloa species. Further, Pacheco et al. (2011) insisted that species of the genus Urochloa (ruziziensis and brizantha) at 60 and 75 DAS had the lowest dry matter rates when compared to millet. After this period, accumulation of the two was higher than that of millet and confirmed the slow initial growth of Urochloa.

Table 1 - Summary of analyses of variance for plant height (PLH), stem diameter (STD), dry mass of the aerial part (DMA), diameter of the capitulum (DCA), mass of achenes per capitulum (MAC), number of achenes per capitulum (NAC), mass of one thousand achenes (MTA), harvest index (HRI) and productivity of achenes (PRA) (Campo Novo do Parecis - MT, 2017)

\begin{tabular}{lccc}
\hline Characteristics & Fvalue $^{1}$ & CV $(\%)^{2}$ & $\mathrm{GA}^{3}$ \\
\hline PLH $(\mathrm{cm})$ & 0.29 & 7.21 & 167.1 \\
STD $(\mathrm{mm})$ & 1.08 & 7.68 & 23.8 \\
DMA $\left(\mathrm{t} \mathrm{ha}{ }^{-1}\right)$ & 0.96 & 15.66 & 6.11 \\
DCA $(\mathrm{cm})$ & 0.17 & 8.96 & 16.6 \\
MAC $(\mathrm{g})$ & 0.71 & 22.28 & 41.5 \\
NAC & 0.45 & 14.23 & 1003 \\
MTA $(\mathrm{g})$ & 0.21 & 12.53 & 56.9 \\
HRI & 0.96 & 14.63 & 0.44 \\
PRA $\left(\mathrm{kg} \mathrm{ha}^{-1}\right)$ & 1.35 & 12.56 & 2766.6 \\
\hline
\end{tabular}

${ }^{1}$ significant at $5 \%$ probability, ${ }^{2} \mathrm{CV}=$ Coefficient of variation; ${ }^{3} \mathrm{GA}=$ general average.

Table 2 - Means of the treatments for plant height (PLH), stem diameter (STD), aerial part dry mass (DMA), diameter of the capitulum (DCA), mass of achenes per capitulum (MAC), number of achenes per capitulum (NAC), mass of one thousand achenes (MTA), harvest index (HRI) and productivity of achenes (PRA) (Campo Novo do Parecis - MT, 2017).

\begin{tabular}{|c|c|c|c|c|c|c|}
\hline \multirow{2}{*}{ Characteristics } & \multicolumn{6}{|c|}{ Seeding rates } \\
\hline & 0 & 200 & 400 & 600 & 800 & 1000 \\
\hline PLH (cm) & 171.3 & 169.3 & 166.2 & 162.5 & 168.8 & 164.7 \\
\hline STDT $(\mathrm{mm})$ & 22.26 & 24.88 & 23.15 & 24.5 & 24.13 & 23.98 \\
\hline DMA $\left(\mathrm{t} \mathrm{ha}^{-1}\right)$ & 6.06 & 6.52 & 5.40 & 6.55 & 5.72 & 6.38 \\
\hline $\mathrm{DCA}(\mathrm{cm})$ & 16.5 & 16.6 & 17.1 & 16.6 & 16.7 & 16.2 \\
\hline MAC $(g)$ & 47.6 & 41.4 & 43.0 & 41.2 & 35.7 & 40.0 \\
\hline NAC & 986 & 1069 & 1002 & 1015 & 925 & 1025 \\
\hline MMA (g) & 57.1 & 57.2 & 58.0 & 59.0 & 54.7 & 55.3 \\
\hline $\mathrm{HRI}$ & 0.50 & 0.41 & 0.44 & 0.42 & 0.44 & 0.45 \\
\hline PRA (kg ha-1) & 2721.9 & 3138.0 & 2847.8 & 2609.3 & 2670.1 & 2612.9 \\
\hline
\end{tabular}

Regard to competition with other species, the sunflower crop is efficient 30 days after emergence. According to Silva et al. (2013), the plant exerts crop control and overshadows the other species. However, since in current analysis seedlings of $U$. ruziziensis started to emerge only 8 DAS, or rather, 3 DAE of sunflower seedlings, a low scale interspecies competition ensued, with low negative effects on the sunflower development.

It should be underscored that total prevention period against interference (PPAI), or rather, the period in which the crop should be maintained free of weeds, is approximately $39 \mathrm{DAE}$ in the summer and $34 \mathrm{DAE}$ in the winter. Consequently, weeds that infest the area after this period do no cause any significant damage to the crop (Silva et al., 2013). The above corroborates reports by Alves et al. (2013) who registered that PPAI was 37 and 43 DAE respectively for genotypes
Embrapa 122 and Helio 358.

The non-interference of intercropping on the sunflower development may be due to the fact that $U$. ruziziensis has a slow development up to 60 DAS and also to the fact that the sunflower is an efficient crop competing with other species as from 30 DAS, corroborating evidence by Timossi et al. (2007) and Pacheco et al. (2008). Further, Souza et al. (2015) did not report any influence of intercropping (sunflower + $U$. ruziziensis) as a single factor in the sunflower's characteristics. However, interaction between intercropping and seeding period and between intercropping and spacing between rows $(0.45$ and $0.90 \mathrm{~m})$ was influential and demonstrated that intercropping influence is related to other factors in the system.

In their research in which they evaluated productive and nutritional characteristics of sunflower and $U$. brizantha in different forager systems and in offsea- 
son intercropping in Rio Verde GO Brazil, Santos et al. (2016) reported differences in the productivity of achenes only when intercropping occurred on the same seeding row of the sunflower. One may conclude that the intercropping of sunflower and species of the genus Urochloa is feasible to produce chaff impairing the development and productivity of the sunflower crop.

Further studies may be undertaken involving technical factors such as spacing, plant populations, intercropping by different species, delayed seeding when compared to simultaneous one, seeding periods and others that affect the system. Research would repeat assays in consecutive years to evaluate the influence of environmental factors and take into account eventual climatic difference between agricultural years.

\section{Conclusion}

The development and productivity of the sunflower are not affected by seeding rates of Urochloa ruziziensis when seeded simultaneously.

\section{Acknowledgements}

The authors would like to thank the research Group in Phytotechnicity (GPF) of the IFMT, campus Campo Novo do Parecis, for their help and support in current assay.

\section{References}

Alves GDS, Tartaglia FDL, Rosa JC, Lima PC, Cardoso GD, Beltrão NEDM (2013) Períodos de interferência das plantas daninhas na cultura do girassol em Rondônia. Revista Brasileira de Engenharia Agricola e Ambiental 17(3):275-282.

Castro CD, Farias JD (2005) Ecofisiologia do girassol. Girassol no Brasil. Embrapa Soja, p. 163-218.

Conab - Companhia Nacional de Abastecimento (2018) Sétimo levantamento de avaliação da safra 2017/18. Disponível em: $<$ https://www.conab.gov.br/index.php/infoagro/safras/graos>. Acesso em 23 abr. 2018.

Dalchiavon FC, Carvalho MP, Freddi OS, Andreotti M, Montanari R (2011) Variabilidade espacial da produtividade do feijoeiro correlacionada com atributos químicos de um Latossolo Vermelho Distroférrico sob sistema de semeadura direta. Bragantia 70(4):908915.

Dallacort R, Martins JA, Inoue MH, de Freitas PSL, Coletti AJ (2011) Distribuição das chuvas no município de Tangará da Serra, médio norte do Estado de Mato Grosso, Brasil. Acta Scientiarum. Agronomy 33(2): 193--200.
Embrapa - Empresa Brasileira de Pesquisa Agropecuária (2013) Centro Nacional e Pesquisa em Solos. Sistema brasileiro de classificação de solos, Brasília. 306p.

Ferreira DF (2011) Sisvar: a computer statistical analysis system. Ciência e agrotecnologia 35(6):1039-1042.

Gontijo Neto MM, Alvarenga RC, Pereira Filho IA, Cruz JC, Rodrigues JAS (2006) Recomendações de densidades de plantio e taxas de semeaduras de culturas anuais e forrageiras em plantio consorciado. Embrapa Milho e Sorgo-Comunicado Técnico (INFOTECA-E).

Gontijo Neto MM, Leite CDP, Uba MA, Vasconcelos FV, Pereira Filho IA, Cruz JC (2009). Avaliação de girassol e forrageiras tropicais perenes em cultivo consorciado. Embrapa Milho e Sorgo-Boletim de Pesquisa e Desenvolvimento (INFOTECA-E).

Leite RMVB, Brighenti AM, Castro C (2005) Girassol no Brasil. Embrapa Soja. 641 p.

Machado LAZ, Assis PD (2010) Produção de palha e forragem por espécies anuais e perenes em sucessão à soja. Pesquisa Agropecuária Brasileira 45(4):415-422 .

Marcelo AV, Corá JE, Fernandes C (2012) Sequências de culturas em sistema de semeadura direta. IIDecomposição e liberação de nutrientes na entressafra. Revista Brasileira de Ciência do Solo 36(5):1568-1582 .

Nepomuceno MP, Varela RM, Alves PL, Martins JVF (2012) Períodos de dessecação de Urochloa ruziziensis e seu reflexo na produtividade da soja RR. Planta Daninha 30(3):557-565.

Noce MA, Souza IF, Karam D, França AC, Maciel GM (2008) Influência da palhada de gramíneas forrageiras sobre o desenvolvimento da planta de milho e das plantas daninhas. Revista Brasileira de Milho e Sorgo 7(3):265-278.

Pacheco LP, Leandro WM, Almeida Machado PLO, Assis RL, Cobucci T, Madari BE, Petter FA (2011) Produção de fitomassa e acúmulo e liberação de nutrientes por plantas de cobertura na safrinha. Pesquisa Agropecuária Brasileira 46(1):17-25.

Pacheco LP, Pires FR, Monteiro FP, Oliveira Procópio S, Assis RL, Carmo ML, Petter FA (2008) Desempenho de plantas de cobertura em sobressemeadura na cultura da soja. Pesquisa Agropecuária Brasileira 43(7):815-823.

Pimentel-Gomes F (2009) Curso de estatística experimental, FEALQ. 451p. 
Santos CB, Pinho Costa KA, Oliveira IP, Costa Severiano E, Costa RRGF, Silva AG, Silva JT (2016) Production and nutritional characteristics of sunflowers and paiaguas palisadegrass under different forage systems in the off season. Bioscience Journal 32(2):460-470.

Silva RR, Reis MR, Mendes KF, Aquino LÂ, Pacheco DD, Ronchi CP (2013) Períodos de interferência de plantas daninhas na cultura do girassol. Bragantia 72(3):255-261.
Souza RF; Silva IM; Pellin DMP, Bergamin AC, Silva RP (2015) Características agronômicas do cultivo de girassol consorciado com Brachiaria ruziziensis. Revista Ciência Agronômica 46(1):110-116.

Timossi PC, Durigan JC, Leite GJ (2007) Formação de palhada por braquiárias para adoção do sistema plantio direto. Bragantia 66(4):617-622.

Vianello RL, Alves AR (2004) Meteorologia básica e aplicações. Viçosa: UFV. 449 p. 